\title{
ESTUARINE MANAGEMENT AREAS: A PRIORITY RANKING SYSTEM
}

\author{
by \\ H.F. OLSEN ${ }^{1}$ )
}

\begin{abstract}
The Queensland Fisheries Service is the instrumentality responsible for administration of fisheries matters within Queensland, Australia. The Fisheries Act provides legislation to protect, conserve, manage and develop the aquatic resources of the State.

As a means of evaluating resource data a priority ranking system is proposed which provides for both quantitative and qualitative assessments of estuaries in terms of regional planning for best land use.
\end{abstract}

The State of Queensland, Australia, comprises the north-eastern corner of the continent, and has its south-eastern border at about longitude $153^{\circ}$ East, latitude $28^{\circ} 10^{\prime}$ South and its north-western boundary at about longitude $138^{\circ}$ East, latitude $16^{\circ} 30^{\prime}$ South. The Queensland Fisheries Service has the task of establishing the nature, distribution and size of fisheries resources and the responsibility of managing those resources in accordance with community needs.

In the past, fisheries management within Queensland waters was often based on the imposition of restraints upon both commercial and recreational fishermen intended to ensure that the wild fish stocks were exploited at the maximum sustainable yield for the benefit of the community.

In the late 1960's however it was recognized that such regulatory measures contributed nothing towards combating some of the major causes of the diminishing quality of the estuarine environment represented by the loss both of habitat formerly available to marine animals for activities such as feeding, reproducing and obtaining shelter from natural predators and of traditional fishing grounds and recreational areas.

To offset the loss of areas of significant ecological value as a result of uncontrolled waterside development with its associated dredging and reclamation operations, it was necessary to arrive at a method of protecting selected areas from further change. This was achieved by the setting aside by the State legislature of conservation areas under the title of "Fisheries Habitat Reserves".

1) Queensland Fisheries Service, Queensland, Australia. 


\section{H.F. OLSEN}

Within these reserves total protection is given to both mangroves and other plant life as well as specified marine organisms (anemones, annelid worms, ascidians, echinoderms). Removal, disturbance or destruction of the sea-bed or deposition of filling is prohibited. Matter may not be discharged into a Habitat Reserve which may be deleterious to marine life or which may alter the physical or chemical environment thereof. Normal fishing operations, both commercial and sport, may be carried out by all lawful means.

With the introduction of legislation in the year 1968, criteria were set down for selection of recommended areas. These define suitable areas as being ... tracts of land comprising large, unfragmented expanses of: (i) marine grass beds;

(ii) organically rich mud flats, sand banks or sand bottoms with dense populations of such burrowing biota as yabbies and soldier crabs (Mictyris longicarpus);

(iii) well developed mangrove swamps; or

(iv) areas with a benthic community exhibiting rare or unusual features.

Concurrently with the establishment of the first Habitat Reserves, there also arose a general recognition that the coastal zone of Queensland and particularly those sections close to the major cities, requires special consideration concerning land-use in the best interest of the community. MCMICHAEL (1972) summarises the problem in respect to New South Wales, our neighbouring State to the south; Queensland, with its longer and more complex coast-line, and its recent development of completely new port and industrial outlets, has also recognised the urgency of the need for coastal management.

The Queensland Government in November 1972 set up environmental protection legislation and a "procedural manual for environmental studies" in Queensland was published. These procedures are currently applied to major development works in the State; the Fisheries Service is an Advisory Body in matters affecting the aquatic environment.

In 1973/74, a review was undertaken of the manner in which fisheries interests could best be served both in providing zoning of fisheries management areas and in an advisory capacity for resource studies and the assessment of the environmental impact of construction work etc. This review extended to the integration with fisheries needs of similar studies carried out in connection with the "Moreton region, non-urban land suitability study", conducted by the Queensland Department of Primary Industries. In this study, MARTIN (1974) established criteria for evaluation of Habitat Suitability for Fauna whilst DURRINGTON (1974) in the same Study, established a Reserve Suitability for Flora rating. 
DURRINGTON (1974) in surveying vegetation of the Moreton region (south-east Queensland) had included the wetland and mangrove vegetation. These methods only partially met the needs of the Fisheries Service and to enable evaluation of fisheries needs more accurately, the inclusion of additional categories was necessary. Table 1 sets out the criteria established by the Service to arrive at a rating of the value to fisheries of a particular study area, viz. "intrinsic value". The procedure was based on the assessment of habitat areas (principally areas of mangrove, and/or sea-grass) on the assumption that:

(i) a method was required to meet the already defined criteria;

(ii) short term surveys of dynamic situations on a localised basis eg. fish populations, hydrology, were inadequate for the needs of regional planning; and

(iii) salt marsh, mangrove, and sea-grass

areas are the most common habitat features capable of simple estimation in Queensland waters. Some $5,000 \mathrm{~km}^{2}$ of mangroves and $8,000 \mathrm{~km}^{2}$ of salt marsh and clay-pan occur in the principal estuaries, whilst sea-grass meadows $(12,500 \mathrm{ha})$ are a major component of south-east Queensland's estuaries.

The method provides an evaluation of the areas of mangroves, sea-grass, mud and sand-bank zones as a composite measurement in Category B. Sections E \& F include information on substrate use and structural form of vegetation, particularly in relation to mangroves, as a modification of the classification by SPECHT (1970) shown in Table II.

Extensive use is made of remote sensing in arriving at the information in-put for this rating. Landsat imagery, both as colour-composites and as individual sensor bands provides initial analysis of vegetation at a regional and watershed level. For detailed interpretation and location of ground truth data stations, the study area, to an arbitrary width of $3 \mathrm{~km}$ above High Water level, is flown at a nominal scale of $1: 12,000$ in normal colour stereophotography, standard format (23 X $23 \mathrm{~cm})$. Additional low-level $(200 \mathrm{~m})$ oblique photography is flown by the ground truth team in infra-red false colour and normal colour for interpretation of specific vegetation associations, tidal areas, clay pans, etc. There is a significant saving of time by the use of remote-sensing. The classical approach to estuarine studies, relying solely on ground investigation required approximately 10 times the man-hours for one comparable study area within reasonably difficult terrain (Rhizophora shrub-land). The mapping output is shown in Figure I. With stereophoto coverage at a scale of $1: 12,000$ and familiarization with the study area in the course of obtaining the infra-red false colour photography at $200 \mathrm{~m}$ flying height, subsequent field check has shown correct identifi- 


\section{H.F. OLSEN}

TABLE I. (habitat evaluation). Intertidal Lands: Intrinsic value rating for fisheries

A. PRESENT DEGREE OF DISTURBANCE (HUMAN USE)

1. No disturbance;

2. Slight to moderate disturbance - eg. Boat Ramp with access road etc.

3. Major draining or ditching. Adjacent land use adversely affects area. Total destruction (fill or bunding to cut off water).

B. SIZE *

1. Greater than 40 hectares;

2. 20 - 40 ha;

3. $12-20$ ha;

4. 8- 12 ha;

5. less than 8 ha.

C. COMPACTNESS AND CONFIGURATION *

1. Compact with regular boundaries;

2. Compact with irregular boundaries;

3. Non-compact;

4. Unsuitable configuration.

D. SURROUNDING LAND USE

1. Not exploited for mining, timber, pasture, cropping, or urban use;

2. Exploited for forestry (controlled harvesting of natural stocks, replenishment with native species);

3. Exploited for pastoral, agricultural, exotic timber plantations, or revegetated surface mining areas;

4. Exploited for urban and/or industrial use.

E. FAUNA SUITABILITY

1. High: Burrows, worm or crab casts evident throughout area;

2. Medium: $50 \%$ use, remainder available or shows evidence of past use;

3. Low: Less than $20 \%$ of area shows active occupation.

F. STRUCTURAL FORM

1. $\quad$ Closed or Open Forest or Scrubland; (Dense to Mid Dense cover);

2. Sparse or very sparse Woodland etc. (Moderate Detrital Input);

3. Open clay-pan, open grassland (salt marsh); (Low Detrital Input).

* Categories for Size, Compactness and Configuration, and Surrounding Land Use follow DURR1NGTON(1974). Durrington's category for Position in Catchment is incorporated in Category 1 (Degree of Disturbance). 
TABLE II. Structural forms of vegetation in Australia (After SPECHT 1970)

\begin{tabular}{|c|c|c|c|c|}
\hline \multirow{2}{*}{$\begin{array}{l}\text { Life Form and } \\
\text { Height of } \\
\text { Tallest } \\
\text { Stratum }\end{array}$} & \multicolumn{4}{|c|}{ Projective Foliage Cover of Tallest Stratum } \\
\hline & Dense $(70-100 \%)$ & Mid Dense $(30-70 \%)$ & Sparse $(10-30 \%)$ & Very Sparse $(<10 \%)$ \\
\hline $\begin{array}{l}\text { Trees }>30 \mathrm{~m} \\
\text { Trees } 10-30 \mathrm{~m} \\
\text { Trees } 5-10 \mathrm{~m}\end{array}$ & $\begin{array}{l}\text { RATING } \\
\text { Tall closed forest } \\
\text { Closed-forest } \\
\text { Low closed-forest }\end{array}$ & $\begin{array}{l}\text { ONE } \\
\text { Tall open-forest } \\
\text { Open-forest } \\
\text { Low open-forest }\end{array}$ & $\begin{array}{l}\text { RATING } \\
\text { Tall woodland } \\
\text { Woodland } \\
\text { Low woodland }\end{array}$ & \begin{tabular}{|l} 
TWO \\
Tall open-woodland \\
Open-woodland \\
Low open-woodland
\end{tabular} \\
\hline $\begin{array}{l}\text { Shrubs } 2-8 \mathrm{~m} \\
\text { Shrubs } 0-2 \mathrm{~m}\end{array}$ & $\begin{array}{l}\text { Closed-scrub } \\
\text { Closed-heath }\end{array}$ & $\begin{array}{l}\text { Open-scrub } \\
\text { Open-heath }\end{array}$ & $\begin{array}{l}\text { Tall shrubland } \\
\text { Low shrubland }\end{array}$ & $\begin{array}{l}\text { Tall open-shrubland } \\
\text { Low open-shrubland }\end{array}$ \\
\hline $\begin{array}{l}\text { Herbs, (incl. } \\
\text { moss, ferns, } \\
\text { Hemicrypto- } \\
\text { phytes, geo- } \\
\text { phytes, thero- } \\
\text { phytes, hy- } \\
\text { drophytes, } \\
\text { halophytes }\end{array}$ & $\begin{array}{l}\text { Closed-herbland } \\
\text { Closed-tussock } \\
\text { grassland } \\
\text { Closed grassland } \\
\text { Closed-herbfield } \\
\text { Closed sedgeland } \\
\text { Closed fernland }\end{array}$ & $\begin{array}{l}\text { Herbland } \\
\text { Tussock grass- } \\
\quad \text { land } \\
\text { Grassland } \\
\text { Herbfield } \\
\text { Sedgeland } \\
\text { Fern land }\end{array}$ & $\begin{array}{l}\text { Open-herbland } \\
\text { Open-tussock } \\
\text { grassland } \\
\text { Open grassland } \\
\text { Open-herbfield } \\
\text { Open-sedgeland } \\
\text { Open-fernland } \\
\text { RATING }\end{array}$ & THREE \\
\hline
\end{tabular}




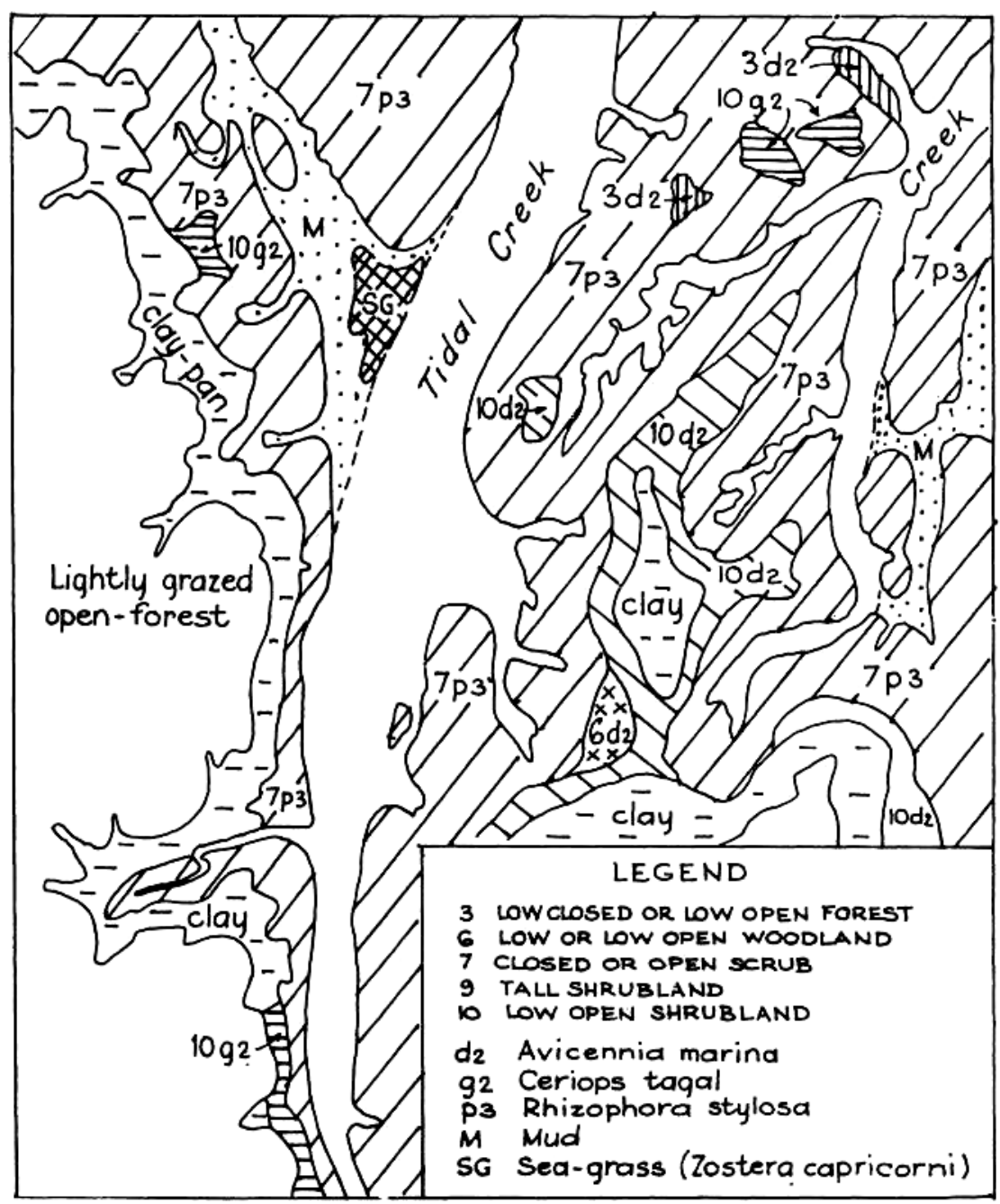

Figure 1. MANGROVE AREA Structural Form and Species Occurrence. 
cation of structural form and species in excess of $90 \%$.

The rating of intrinsic value however does not provide a comparative assessment of either overall regions or of estuarine systems. The rating meets, as was intended, the criteria for selection of Fisheries Habitat Reserves but does not serve any direct purpose in terms of zoning on a regional basis for the needs of coastal management.

RATCLIFFE (1971) set down nine criteria for the selection of nature reserves; briefly summarised as extent, naturalness, richness, diversity, fragility, representativeness, research and educational value, recorded history and potential value. Data about fauna are harder to collect; particularly is this so in the case of marine animals. It was therefore decided to adopt the assumption that faunistic richness is related to vegetation structure, ELTON and MILLER (1955).

A Priority Ranking system was therefore introduced to provide data input on a watershed or estuary basis for ultimate incorporation in regional studies. A "Region" is usually an administrative or statistical division incorporating similar watersheds.

The system currently in use employs the basic category of intrinsic value rating shown in Table I, with additional categories to allow for development of a management strategy on a regional basis.

These categories comprise:

1. Intrinsic value:

The value to fisheries of habitat zones in the study area, in their present state.

2. Common-ness:

Common-ness within the region of the community, in terms of vegetation, or features or habitat zones of ecological value to fisheries (A measure of the importance and amount of each feature in the present landscape of the region).

3. Diversity:

The number of community or habitat zones or natural features within a watershed or estuary.

4. Use-value:

An indicator of the area's value as measured by present and potential fisheries, recreational, scientific or other aquatic-based use. Use is considered in the context of the conservation of the area for the long-term benefit of the community.

5. Future human impact:

A rating of the area's security in respect to the maintenance of the existing environment. 


\section{H.F. OLSEN}

Table III assembles a comparison of the criteria used by the Service and those proposed by TANS (1974), GOLDSMITH (1975) and GEHLBACH (1975) in dealing with the ranking of conservation areas. The system incorporates an additive and multiplicative scoring of features in each study area in order of their importance to fisheries, with the lowest score indicating least disturbance hence greatest value for conservation or fisheries use. Point Allocation for each category is set down in Table IV.

When Future Hinterland Use is under consideration a matrix treating each variable as a "plus", ie. (beneficial), "nil", or "minus" (harmful) effect on the aquatic environment is in use (Table V).

Estuarine Management decisions from a fisheries viewpoint are based on the premise that large scale disturbance of any tidal area of significant value to fisheries is opposed. Multiple use of estuarine areas must comply with the constraints that such use:

(i) does not directly destroy or adversely affect areas of significant ecological value;

(ii) provides water dependent facilities of community benefit at least loss of habitat; and

(iii) does not involve irreversible changes of environment of a nature or scale which would be inimical to fisheries.

With these guide lines established, and making use of the Priority Ranking Values three management zones may be established:

(a) area suitable for reservation (Either as a Marine Park, Fisheries Habitat Reserve, Sanctuary or similarly "protected" area);

(b) a general management zone in which constraints on conflicting multiple use may be implemented;

(c) a development zone in which existing development or potential development in areas of limited ecological or fisheries value provides a community benefit to offset the loss of tidal lands.

\section{SUMMARY}

The evaluation systems outlined in this paper are those currently in use by the Queensland Fisheries Service. Direct assessment of fish stocks in not attempted. The assessments have provided a useful basis for estuarine zoning proposals for submission to the legislature of the State. If past history is any indication, as the storage of base-line data increases and the needs of coastal management become more clear, the present evaluation systems will be further modified to provide a more definitive ranking. 
TABLE III. Priority ranking.

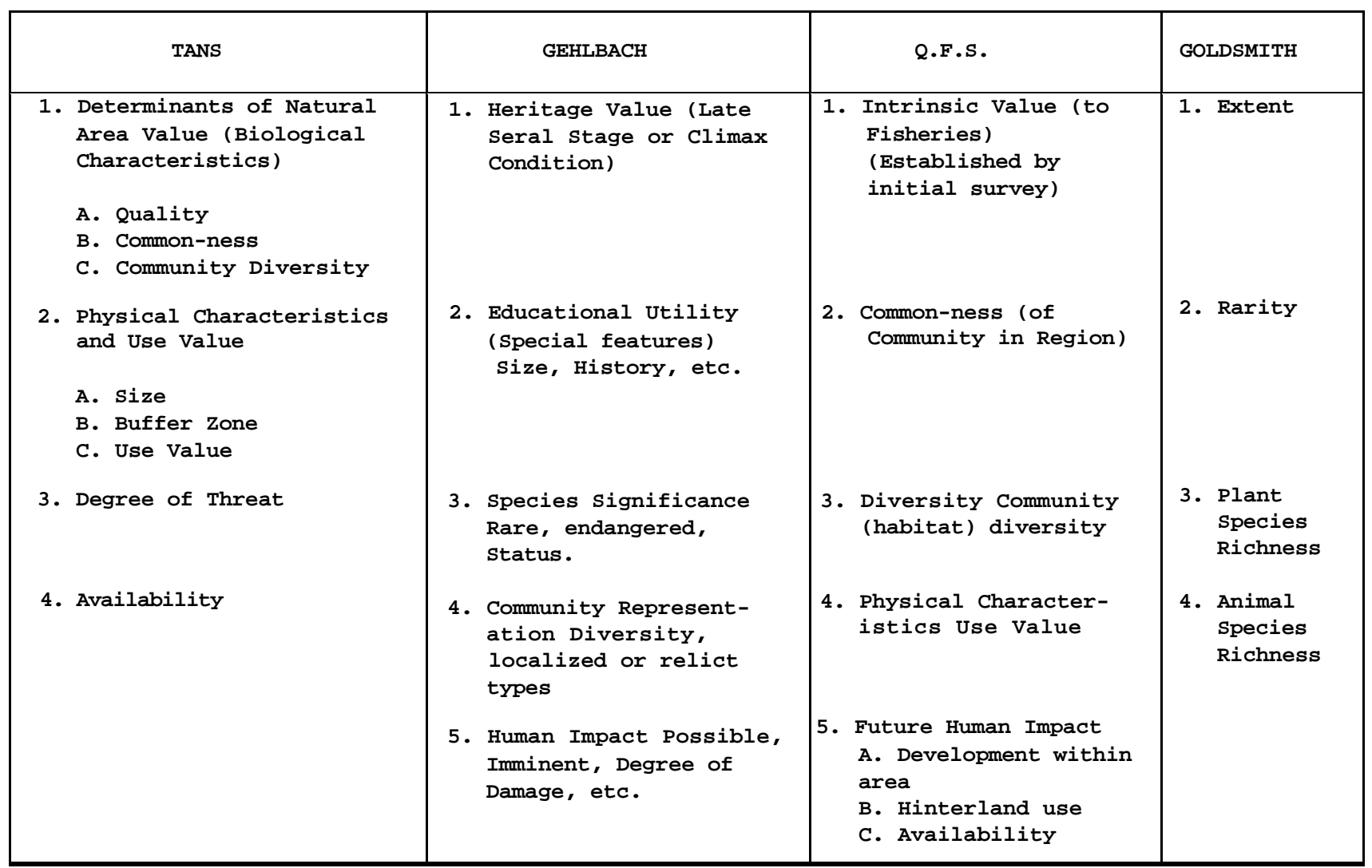




\section{H.F. OLSEN}

TABLE IV. Priority ranking of estuarine systems

1. INTRINSIC VALUE: Point Allocation:

Highest Value - Area substantially meets all criteria for Intrinsic assessment. (Evaluation gives low sub-rating input) $\quad \ldots 0$ High Value - Meets most criteria for Intrinsic Value, low hinterland damage to fisheries $\ldots 1$ Medium Value - Subject to existing loss of Fisheries value, integrity of area lessened .....2 2 Low or Minimal Value - Fails to meet most of criteria (high "loss" sub-rating from evaluation) .... 3

2. COMMON-NESS: Point Allocation:

Very Uncommon - Low acreage in pre-settlement vegetation and present vegetation, restricted occurrence, the presence of two or more endangered species or the rare or only known occurrence of a non-botanical feature eg. inshore coral reef or marine feature of value to fisheries $\ldots .0$ Uncommon - Moderate amount of type in pre-settlement vegetation and/or partial destruction of type, moderate amount of type in region, no known rare or endangered species or marine feature $\quad \ldots .1$ Common - Frequent to abundant in the present landscape, or an adequate representation of the type exists in the region $\ldots 2$

(Multiplier X 2)

3. DIVERSITY: Point Allocation:

Great Diversity - Four or more community types or features $\quad \ldots 1$ Moderate Diversity — Two or three types or features $\ldots .2$ No Diversity - Single community type or feature $\ldots 3$

\section{(Multiplier X 3)}

\section{USE-VAL UE: Point Allocation:}

Outstanding Value - Supports or is capable of supporting a significant assemblage of marine animals $\ldots 1$

High Value - Present use of value to fisheries, indications of potential future expansion in use $\ldots 2$

Medium Value - Of limited present use, future expansion of use unlikely

Low Value - No significant or probable use of the natural resource $\quad \ldots .4$

(Multiplier X 4) 


\section{ESTUARINE MANAGEMENT AREAS}

\section{FUTURE HUMAN IMPACT:}

A. Future Development within the estuary, ie. Direct loss of Habitat. Little likelihood of disturbance ... 1

Threat is moderate, disturbance of minor nature possible in future $\ldots .2$ Threat is imminent for part of area

... 3

Severe threat, major portion of area currently being developed or destroyed

B. Future Hinterland Use involves an evaluation of regional and local planning and development schemes, port and industrial activities, land-use patterns in the watershed and potential changes in land-use.

Point Allocation:

Existing land-use within $3 \mathrm{~km}$ of High Water Mark is expected to continue without detriment to fisheries .... 0 Potential land-use within $3 \mathrm{~km}$ of High Water Mark is compatible with fisheries management .... 1 Regional planning indicates nodes of development affecting parts of the area Regional planning indicates total development of large parts of the area for non-compatible use

C. Availability. In most instances the areas under study comprise inter-tidal or tidal lands under State control. However, where specific locations are under study, e.g. additional "protection" for an area of high ecological value, there is need for quantification under this heading:

Available by co-operation of local or State authority Available by resumption at low cost $\ldots 0$ Available at high cost 


\section{H.F.OLSEN}

PRIORITY RANKING: "Example. Lowest Possible Score $\quad$.....12 Highest Possible Score $\quad \ldots 77$

(a) Hervey Creek

\begin{tabular}{lccc}
\hline \multicolumn{1}{c}{ Feature } & Rating & Multiplier & Point Score \\
\hline Intrinsic Value & 0 & 1 & 0 \\
Common-ness & 1 & 2 & 2 \\
Diversity & 2 & 3 & 6 \\
Use-Value & 2 & 4 & 8 \\
Future Human Impact: & & & 5 \\
$\quad$ A. Within Estuary & 1 & 5 & 5 \\
$\quad$ B. Hinterland & 1 & 5 & 0 \\
$\quad$ C. Availability & 0 & 5 & \\
$\quad$ & & & 26 \\
TOTAL & & & \\
\cline { 2 - 4 } & & &
\end{tabular}

Conclusion: The area has potential value as an area for reservation.

(b) Manly River

\begin{tabular}{lccc}
\hline \multicolumn{1}{c}{ Feature } & Rating & Multiplier & Point Score \\
\hline Intrinsic Value & 1 & 1 & 1 \\
Common-ness & 2 & 2 & 4 \\
Diversity & 2 & 3 & 6 \\
Use-Value & 3 & 4 & 12 \\
Future Human Impact: & & & 15 \\
$\quad$ A. Within Estuary & 3 & 5 & 10 \\
$\quad$ B. Hinterland & 2 & 5 & 10 \\
$\quad$ C. Availability & 2 & 5 & 58 \\
TOTAL & & &
\end{tabular}

Conclusion: Not suitable for reservation. Management procedures necessary to offset probable effects of future use. 
Table V. TABLE V. A matrix on the environment (see text).

\begin{tabular}{|c|c|c|c|c|c|c|c|c|c|c|c|c|c|c|c|c|c|c|c|c|}
\hline \multirow{2}{*}{\multicolumn{3}{|c|}{ 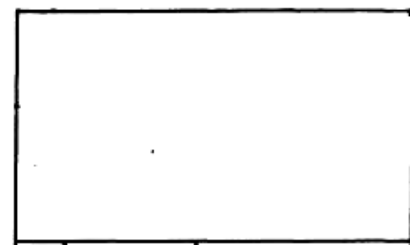 }} & \multicolumn{4}{|c|}{ MODIFICATION. } & \multicolumn{3}{|c|}{ EXTRACTION. } & \multicolumn{2}{|c|}{$\begin{array}{l}\text { WATERSHED } \\
\text { USE. }\end{array}$} & \multicolumn{3}{|c|}{\begin{tabular}{|l} 
RESOURCE \\
RENEWAL
\end{tabular}} & \multicolumn{3}{|c|}{\begin{tabular}{|c|} 
WASTE \\
DISPOSAL.
\end{tabular}} & \multicolumn{3}{|c|}{$\begin{array}{l}\text { PESTICIDES } \\
\text { ETC }\end{array}$} \\
\hline & & & 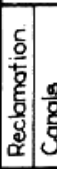 & 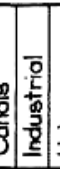 & 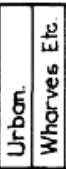 & 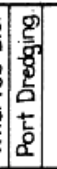 & 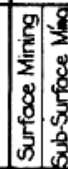 & 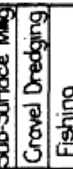 & 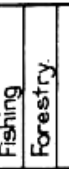 & 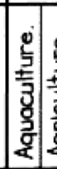 & 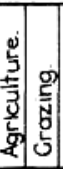 & 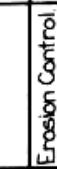 & 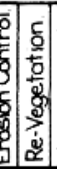 & 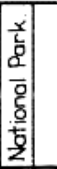 & \begin{tabular}{|l|}
0 \\
$\vdots$ \\
$\vdots$ \\
$\vdots$ \\
$\vdots$
\end{tabular} & 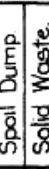 & & 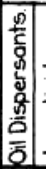 & 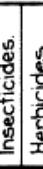 & \\
\hline \multirow{9}{*}{ 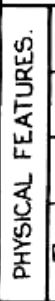 } & EARTH & Soils, & & & & & & & & & & & & & & & & & & \\
\hline & EARIA. & Landform. & & & & & & & & & & & & & & & & & & \\
\hline & \multirow{2}{*}{ WATER. } & Ocean & & & & & & & & & & & & & & & & & & \\
\hline & & Fresh & & & & & & & & & & & & & & & & & & \\
\hline & \multirow{2}{*}{ CLIMATE } & Micro & & & & & & & & & & & & & & & & & & \\
\hline & & Mocro & & & & & & & & & & & & & & & & & & \\
\hline & \multirow{3}{*}{ PROCESSES } & Floods & & & & & & & & & & & & & & & & & & \\
\hline & & Erosion & & & & & & & & & & & & & & & & & & \\
\hline & & Sedimentation. & & & & & & & & & & & & & & & & & & \\
\hline \multirow{7}{*}{ 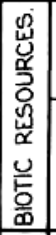 } & \multirow{3}{*}{$\begin{array}{l}\text { MARINE } \\
\text { FLORA. }\end{array}$} & Endangered Species. & & & & & & & & & & & & & & & & & & \\
\hline & & Rare Species. & & & & & & & & & & & & & & & & & & \\
\hline & & Ecosystem Value. & & & & & & & & & & & & & & & & & & \\
\hline & \multirow{4}{*}{$\begin{array}{l}\text { MARINE } \\
\text { FAUNA. }\end{array}$} & Endangered Species & & & & & & & & & & & & & & & & & & \\
\hline & & Fin Fish. & & & & & & & & & & & & & & & & & & \\
\hline & & Shell Fish. & & & & & & & & & & & & & & & & & & \\
\hline & & Ecosystem Value. & & & & & & & & & & & & & & & & & & \\
\hline \multirow{10}{*}{ 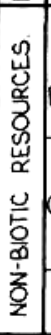 } & \multirow{4}{*}{$\begin{array}{l}\text { LAND USE } \\
\& \\
\text { RECREATION }\end{array}$} & Wetlands. & & & & & & & & & & & & & & & & & & \\
\hline & & Wilderness Spoce. & & & & & & & & & & & & & & & & & & \\
\hline & & Fishing, Booting. & & & & & & & & & & & & & & & & & & \\
\hline & & Scenic, Historic. & & & & & & & & & & & & & & & & & & \\
\hline & \multirow{4}{*}{\begin{tabular}{|c|} 
FACILITIES \\
OWNERSHIP \\
ETC. \\
\end{tabular}} & Crown(Public) Londs. & & & & & & & & & & & & & & & & & & \\
\hline & & Alienoted Londs. & & & & & & & & & & & & & & & & & & \\
\hline & & Utilities. & & & & & & & & & & & & & & & & & & \\
\hline & & Population Density. & & & & & & & & & & & & & & & & & & \\
\hline & \multirow{2}{*}{ HEALTH } & Disease & & & & & & & & & & & & & & & & & & \\
\hline & & Insect Pests. & & & & & & & & & & & & & & & & & & \\
\hline
\end{tabular}




\section{H.F.OLSEN}

\section{ACKNOWLEDGEMENTS}

I wish to record my thanks to the botanists of the Ecology Group, Botany Branch, Department of Primary Industries, whole ready assistance in both field studies and analysis of results has been essential for the execution of the work on which the present method is based. The encouragement and welcome critical appraisal of senior officers of the Queensland Fisheries Service is also acknowledged with gratitude.

\section{BIBLIOGRAPHY}

COORDINATOR-GENERAL'S DEPARTMENT QUEENSLAND 1975. Procedural manual for environment impact in Queensland: $39 \mathrm{pp}$.

DURRINGTON, L. 1974. Flora reserve suitability. Moreton Region, Non-urban land suitability study, 3.1-3.9. Tech. Bull. 11, Department of Primary Industries, Queensland, Australia.

ELTON, C.S. and R.S. MILLER 1974. The ecological survey of animal communities with a practical system of classifying habitats by structural characteristics. $J$. Ecol. 42:460-496.

GEHLBACH, F.R. 1975. Investigation, evaluation, and priority ranking of natural areas. Biol. Conserv. 8(2):79-88.

GOLDSMITH, F.B. 1975. The evaluation of ecological resources in the countryside for conservation purposes. Biol. Conserv. 8(2):89-95.

MARTIN, J. 1974. Land suitability for fauna. Moreton region, non-urban land suitability study, 4.1. - 4.2. Tech. Bull. 11, Department of Primary Industries, Queensland, Australia.

MCMICHAEL, D.F. 1972. Conservation of estuarine regions and the coastal zone. I.U.C.N. Pub. 28(25);363-371.

RATCLIFFE, D.A. 1971. Criteria for the selection of nature reserves. Advmt. Set, London 27:294-296.

SPECHT, R.L. 1970. Vegetation in the Australian Environment. (G.W. LEEPER ed.). C.S.I.R.O. (Aust.) and Melb., 4th ed. Uni. Press, Melbourne, pp. 44-67.

TANS, W. 1974. Priority ranking of biotic natural areas. The Michigan Botanist 13:31-39. 